\title{
Utilization of natural and transplanted Texas salt marshes by fish and decapod crustaceans
}

\author{
Thomas J. Minello, Roger J. Zimmerman \\ National Marine Fisheries Service, Southeast Fisheries Center, Galveston Laboratory, 4700 Avenue U, Galveston, \\ Texas 77550, USA
}

\begin{abstract}
Habitat utilization by fish and decapod crustaceans was compared among 3 transplanted and 3 natural Spartina alterniflora marshes on the Texas (USA) coast during spring 1986. Created marshes had been transplanted on dredged material and were approximately 2 to 5 yr old at the time of sampling. Although conclusions are limited to the spring season, the use of replicate marshes allowed us to test the null hypothesis that transplanted marshes on the Texas coast were equivalent to natural marshes. Mean values for stem density and above-ground biomass of S. alterniflora were consistently higher in the transplanted marshes, and the difference was statistically significant for stem density. Macro-organic matter (MOM) in the upper $5 \mathrm{~cm}$ of sediment was significantly lower in the transplanted marshes. Densities of polychaetes and amphipods within transplanted marshes were positively correlated with this MOM. Transplanted marshes had significantly lower densities of decapod crustacea (primarily daggerblade grass shrimp Palaemonetes pugio and juvenile brown shrimp Penaeus aztecus) compared with natural marshes. This reduced utilization may have been a response to low densities of benthic food organisms, and densities of decapods were positively correlated with densities of prey in sediment cores. In contrast to the utilization pattern of decapods, densities of fish (dominated by the darter goby Gobionellus boleosoma and pinfish Lagodon rhomboides) were similar between natural and transplanted marshes. These small fish may rely on salt marshes more for protective cover than for enhanced food resources, and above-ground structure in the transplanted marshes may have adequately provided this function. Comparisons of functional equivalency between natural and transplanted salt marshes require adequate information on how salt marshes actually function for fish and decapod crustaceans. For example, the use of prey density as an indicator of food value in a marsh can be misleading unless trophic pathways are well understood and access to the marsh surface is considered.
\end{abstract}

\section{INTRODUCTION}

Extensive losses of coastal wetlands have renewed interest in the creation of salt marsh habitats on dredged material. Techniques for transplanting Spartina alterniflora have been developed, and stands of this smooth cordgrass have been established under a variety of coastal conditions (Woodhouse et al. 1972 , Webb 1977, Broome et al. 1988, Broome 1989). There is still considerable controversy, however, over whether these transplanted marshes function like natural salt marshes (Race \& Christie 1982, Broome 1989, LaSalle et al. 1991, Moy \& Levin 1991). Part of this disagreement is caused by the variety of ways that marshes function in coastal ecosystems. For example, the sedi- ment retention and erosion abatement function of marshes can be readily measured and appears replaceable if a marsh can be physically established (see Broome 1989 for review). Success in replacing biological habitat functions that support production of shrimp, crabs, and fishes is more difficult to assess.

Determining whether biological functions have been restored requires information on how marshes provide functions. The problem is readily apparent if we examine provision of food for growth. Historically, salt marshes were mainly thought to contribute to detrital food webs through the exportation of macrophyte detritus into downstream estuaries (Teal 1962, Odum \& de la Cruz 1967, reviewed by Nixon 1980). More recently, the importance of benthic and epiphytic algae 
in the marsh has been recognized in providing a source of food for estuarne anumals (Hannes 1979, Pomeroy et al. 1981, Knox 1986, Peterson \& Howarth 1987. Sullivan \& Moncrelff 1988, 1990) Although physical exportation of detrital matter from marshes can be significant (Nixon 1980, Wiegert \& Freeman 1990), the transfer of marsh carbon to aquatic estuarme predators appears to be facilitated by tidal flushing of small detritivores, herbivores, and omnivores from the marsh into open water (Weisberg et al. 1981, Knelb \& Stiven 1982, Zimmerman \& Minello 1984, Kneıb 1987. McIvor \& Odum 1988). In addition, some large estuarine predators directly exploit marsh surfaces by moving into the marsh on flood tide to feed (Knelb \& Stiven 1982. Weisberg \& Lotnch 1982. Zimmerman \& Minello 1984, Rozas \& Odum 1987, Thomas 1989, Rozas \& LaSalle 1990, Minello \& Zimmerman 1991)

Regional (Zimmerman et al. 1991) and perhaps local (Feljtel et al 1985, Rozas \& Odum 1987. Wiegert \& Freeman 1990, Zımmerman et al. 1990a) differences in the relative importance of these trophic pathways need to be considered in assessing functional salt marsh value for estuarine decapods and fish. If marshes provide food mainly through indirect mechanisms such as the exportation of detritus, the abundance of natant macrotauna on the marsh surface may not be indicative of relative marsh value for these organisms Direct exploitation, however, is extensive in many marshes of the northern Gulf of Mexico (Zimmerman \& Minello 1984. Thomas et al. 1990, Zımmerman et al. 1990b, Baltz et al. 1992. Rozas 1992), thus densities of decapods and fishes and their prey on the marsh surface should reflect habitat value for marshes in this region.

In this paper we examine utılization of 3 transplanted salt marshes and adjacent natural marshes by comparing spring densities of fishes and decapod crustaceans. Densities of infaunal prey organisms, the amount of macro-organic matter (MOM) in the sediment, and the above-ground standing crop of Spartina alterniflora were also examined. All marshes were located on the Texas (USA) coast, and the created marshes were planted by the U S. Army Corps of Engineers on maintenance dredge matenal; these marshes ranged from just under 2 yr (East Matagorda Bay) to almost 5 yr (Stedman Island) in age. Conclusions on habitat utılization and functional value are limited to the spring season, but this period is an important time of anımal recruitment in Texas marshes (Zimmerman \& Minello 1984).

\section{METHODS}

Study areas. The Chocolate Bay study area is in a meso- to polyhaline region of the Galveston Bay system approximately $27 \mathrm{~km}$ west-southwest of Gal- veston. Texas (Fig 1) Thus bay system is dominated by Spartina alterniflora marshes, and annual rainfall is around $1.3 \mathrm{~m} \mathrm{yr}^{-1}$ (Climatological Data 1990). An 8.1 ha salt marsh was transplanted on silty clay dredge material along the shoreline of Chocolate Bay in June 1983. The natural marsh we sampled was located $0.5 \mathrm{~km}$ east in Hall's Lake; sedıment in this marsh was silty sand.

The East Matagorda Bay study area is located between the San Bernard and Colorado Rivers near the mouth of Caney Creek. This area of the Texas coast

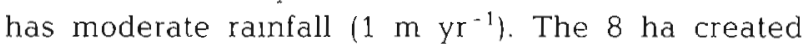
marsh was transplanted in June and July of 1984 on sulty clay dredged from the Gulf Intracoastal Waterway. This marsh is ca $8 \mathrm{~km}$ south of Sargent, Texas. The natural marsh was $1.2 \mathrm{~km}$ southeast, and the sedment contained more sand.

The Stedman Island study area is located in Redfish Bay of the Corpus Christi Bay system about $3 \mathrm{~km}$ south of Aransas Pass, Texas This region of the coast is semiand and subtropical in nature with an average rainfall of $0.8 \mathrm{~m} \mathrm{yr}^{-1}$. The water in this estuanne system was relatıvely clear, and seagrasses, including Thalassia testudinum and Halodule wrightil, were abundant adjacent to the natural and transplanted salt marshes. Natural Spartina alterniflora occurs in the system as narrow fringing marsh but does not predommate as it does at Chocolate Bay and East Matagorda Bay. A 5 ha S. alterniflora marsh was transplanted on sandy dredge materlal in May and June of 1981 on the eastern side of Stedman Island. By the time we sampled

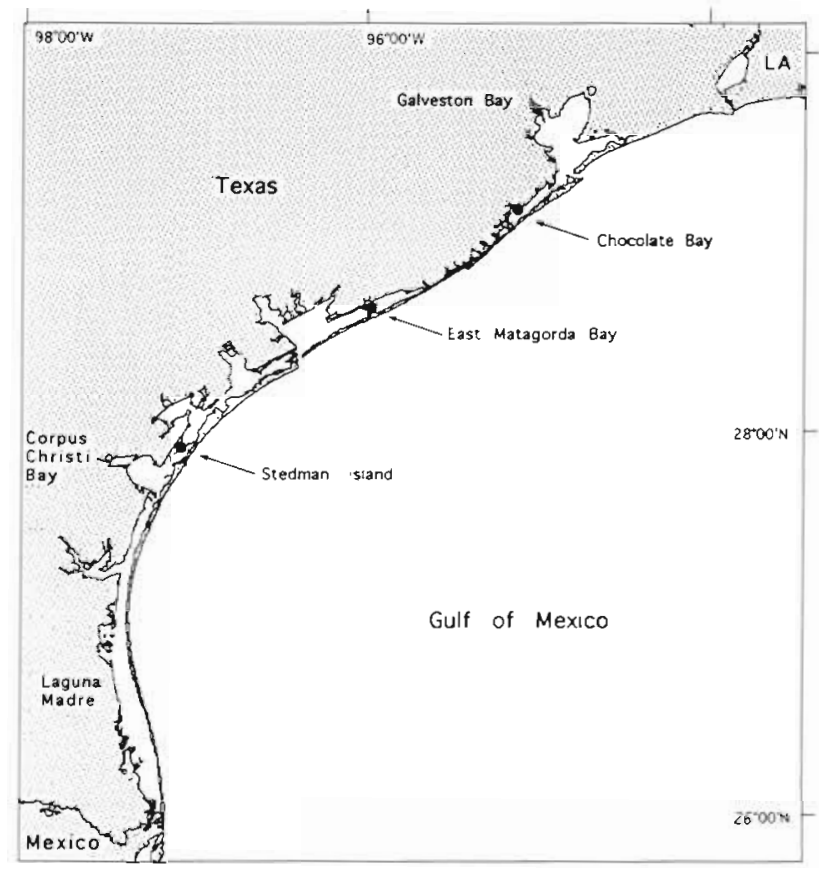

Fig 1 Locations of transplanted and natural Spartina altern!flora marshes along the Texas coast 
the marsh in 1986, much of the inner marsh had died back, apparently due to salt accumulation in poorly flushed sediments. Vegetation along the bay edge and along small channels, however, appeared to be growing vigorously. The natural marsh was located ca $1.3 \mathrm{~km}$ to the east of the transplanted marsh.

All of the marshes in this study were shoreline marshes bordering shallow bays. The vegetation within a few meters of the open water was selected for sampling because the marsh edge is extensively utilized by natant macrofauna (Zimmerman \& Minello 1984, Thomas et al. 1990, Baltz et al. 1992, Rozas 1992). This habitat is subject to frequent inundation by the mixed tides characteristic of the northern Gulf of Mexico (Sasser 1977, Childers et al. 1990, Zimmerman et al. 1991).

Sampling and processing. Samples were collected at the 3 study areas between March 25 and April 17 , 1986; both the transplanted and natural marshes within a study area, however, were sampled on the same day. Four randomly-located sites were sampled within the Spartina alterniflora along the outer edge of each marsh. At each of these sites, a drop sample was collected according to the procedures of Zimmerman et al. (1984). This method employs a large cylinder ( $1.8 \mathrm{~m}$ diameter) that is dropped from a boom on a boat and entraps organisms within a $2.6 \mathrm{~m}^{2}$ area. After the sampler was in place, water temperature and dissolved oxygen were measured using a YSI Model 51B meter, and salinity was measured using an American Optical temperature-compensated refractometer. Water samples were collected for the analysis of turbidity in the laboratory. Maximum and minimum water depth were measured, and sample water depth was recorded as the midpoint between the maximum and minimum depth. A $10 \mathrm{~cm}$ diameter $\left(78.5 \mathrm{~cm}^{2}\right)$ sediment core, that included a clump of $S$. alterniflora, was taken within the drop sampler (near the center) for the collection of small benthic infauna and epifauna. The upper $5 \mathrm{~cm}$ of sediment and the lower $5 \mathrm{~cm}$ of the plant stems were washed on a $0.5 \mathrm{~mm}$ mesh sieve, and the animals and plant material retained on the sieve were preserved in formalin. These animals were assumed to be generally available as prey to large macrofauna. The remaining macrophytes within the drop sampler were clipped at the substratum surface and returned to the laboratory in a large plastic bag. Most of the natant macrofauna trapped in the drop sampler were captured using dip nets while the water was pumped out of the enclosure and through a $1 \mathrm{~mm}$ mesh net. When the sampler was completely drained, animals remaining on the bottom were picked up by hand. The collection was preserved in formalin with Rose Bengal stain.

In the laboratory, turbidity of water samples was measured using an HR Instruments Model DRT 100B nephelometer and a formazin standard. Wet weight of the clipped Spartina alterniflora was recorded, and the number of stems (dead and alive combined) was counted. Drying of plant material between the time of collection and time of weighing (usually 1 d) was assumed to be negligible. If drying did occur, it should have been comparable for the natural and transplanted marshes of any one study area. Fishes, crustaceans, and mollusca from drop samples (collectively referred to as large macrofauna throughout this paper) were identified to species. Crustaceans were measured to the nearest $1 \mathrm{~mm}$ in total length or carapace width. Animal diversity was defined as the total number of species or taxa identified from the 4 samples collected in a marsh.

Organisms from the sieved sediment cores were separated from detritus and plant stems. These small macrofauna are collectively referred to as infauna in this paper, although some epifauna from the surfaces of the sediment and plant stems were undoubtedly collected. Oligochaetes and other organisms buried in Spartina alterniflora stems were assumed to be relatively unavailable as prey and were not removed for counting. Amphipods, tanaids, and polychaete worms were identified to the species level, and remaining organisms were grouped into the lowest feasible taxonomic category. Roots, rhizomes, and detritus from the sediment cores (macro-organic matter, MOM) were separated from $S$. alterniflora stems, dried to a constant weight at $100^{\circ} \mathrm{C}$, and weighed. The number of stems in each core was also counted.

Data analysis. Statistical comparisons were designed to test the null hypothesis that transplanted marshes of 2 to $5 \mathrm{yr}$ in age in Texas were the same as natural marshes for the various observations of animal density and diversity and characteristics of the physical environment, sediment, and Spartina alterniflora. Making the inference to transplanted marshes in general required the use of mean values from each marsh, and the 4 replicate samples within a marsh were considered subsamples. A 1 -way ANOVA with the study area as a blocking variable was used to test for a difference between transplanted and natural marshes (Hicks 1973). This blocking should remove the effects of geographic location and sampling time (within the period between March 25 and April 17). The analysis is comparable to a paired $t$-test with 3 pairs (the study areas) and has relatively low statistical power.

Plots of mean values from each marsh against the sample standard deviation and variance were examined to determine the need for data transformations. Animal densities were positively related to the standard deviation, and the original density values were $\log +1$ transformed before means were calculated for the ANOVAs. Mean above-ground Spartina alterniflora biomass was linearly related to the sample vari- 
Table 1. A comparison of physical and macrophyte characteristics from 3 transplanted salt marshes and adjacent natural marshes along the Texas coast. All collections were made in March-April 1986 except stem densities at both Stedman Island marshes (February 1986). All means are from 4 observations except for sediment macro-organic matter (MOM) at the natural marsh in East Matagorda Bay $(n=3)$

\begin{tabular}{|c|c|c|c|c|c|c|c|c|c|c|c|c|}
\hline & \multicolumn{4}{|c|}{ East Matagorda Bay } & \multicolumn{4}{|c|}{ Chocolate Bay } & \multicolumn{4}{|c|}{ Stedman Island } \\
\hline & \multicolumn{2}{|c|}{ Natural } & \multicolumn{2}{|c|}{ Transplant } & \multicolumn{2}{|c|}{ Natural } & \multicolumn{2}{|c|}{ Transplant } & \multicolumn{2}{|c|}{ Natural } & \multicolumn{2}{|c|}{ Transplant } \\
\hline & Mean & SE & Mean & SE & Mean & $\mathrm{SE}$ & Mean & $\mathrm{SE}$ & Mean & $\mathrm{SE}$ & Mean & $\mathrm{SE}$ \\
\hline Salinity (ppt) & 24.5 & 0.29 & 25.0 & 0.00 & 25.5 & 0.29 & 27.5 & 0.29 & 29.0 & 0.00 & 27.0 & 0.00 \\
\hline Temperature $\left({ }^{\circ} \mathrm{C}\right)$ & 26.2 & 1.13 & 26.2 & 0.74 & 20.0 & 0.06 & 20.9 & 0.27 & 23.3 & 0.12 & 23.8 & 0.25 \\
\hline Dissolved oxygen (ppm) & 7.9 & 0.33 & 8.7 & 1.10 & 8.5 & 0.35 & 8.3 & 0.48 & 8.4 & 0.57 & 10.4 & 0.09 \\
\hline Turbidity (FTU) & 83.3 & 39.94 & 17.0 & 5.45 & 28.0 & 4.92 & 17.0 & 2.61 & 17.5 & 2.40 & 13.8 & 0.85 \\
\hline Sample water depth $(\mathrm{cm})$ & 6.6 & 0.72 & 9.6 & 0.75 & 16.4 & 1.56 & 14.9 & 1.11 & 27.8 & 1.27 & 29.6 & 1.37 \\
\hline $\begin{array}{l}\text { Sediment } \mathrm{MOM} \\
\quad\left(\mathrm{g} \text { dry wt per } 78.5 \mathrm{~cm}^{2}\right)\end{array}$ & 3.6 & 0.24 & 0.6 & 0.19 & 6.8 & 2.12 & 2.4 & 0.44 & 5.7 & 1.28 & 1.7 & 0.06 \\
\hline \multicolumn{13}{|l|}{ Spartina alterniflora } \\
\hline $\begin{array}{l}\text { Above-ground biomass } \\
\left(\mathrm{kg} \text { wet wt per } 2.6 \mathrm{~m}^{2}\right)\end{array}$ & 1.8 & 0.31 & 6.0 & 1.01 & 2.0 & 0.16 & 4.1 & 0.62 & 2.5 & 0.58 & 2.6 & 0.57 \\
\hline $\begin{array}{l}\text { Stem density } \\
\text { (stems per } 2.6 \mathrm{~m}^{2} \text { ) }\end{array}$ & 323.5 & 36.74 & 457.0 & 69.27 & 335.3 & 41.55 & 479.7 & 39.14 & 268.0 & 65.42 & 502.8 & 112.0 \\
\hline
\end{tabular}

ance, and a square-root transformation was applied to this variable. Other variables were not transformed. The data on $S$. alterniflora stem density from Stedman Island were lost, and stem counts from February 1986 (collected with identical methods) were substituted for both the natural and transplanted marshes in this study area.

\section{RESULTS}

There were no significant differences in water salinity, temperature, turbidity, or depth between the natural and transplanted marshes (Table 1; ANOVA: 1,2 df all p's $>0.18$ ). Turbidity at the East Matagorda Bay natural marsh was unusually high, and in part this was due to 1 sample with a turbidity of 200 FTU. If this value was considered an outlier, perhaps caused by disturbance from the sampling crew, the mean turbidity for the natural marsh at this study area would be lowered to 44.3 FTU. Dissolved oxygen at the time of sampling was not significantly different in the overall comparison of natural and transplanted marshes, but mean values were higher in the transplanted marshes of East Matagorda Bay and Stedman Island (Table 1).

Mean stem densities and above-ground biomass for Spartina alterniflora were consistently higher in transplanted marshes compared with natural marshes (Table 1), and there was a significant difference in stem density (Table 2). The weight of MOM in the upper $5 \mathrm{~cm}$ of sediment was significantly lower in the transplanted marshes (Tables 1 \& 2). The mean number of $S$. alterniflora stems in the $10 \mathrm{~cm}$ diameter cores ranged from 5.8 to 11.8 at the 6 marshes, but there was no significant difference in this value between natural and transplanted marshes (ANOVA: $1,2 \mathrm{df} ; F=2.11$; $p=0.28$. Sediment MOM was not significantly correlated with the number of stems in a core $(r=0.26, p=$ $0.22, \mathrm{n}=23$ ).

Mean densities of total infauna from the sediment cores were consistently higher in the natural marshes compared with the transplanted marshes (Fig. 2), although this difference was not statistically significant (Table 2). In East Matagorda Bay, infaunal abundances at both marshes were considerably lower than at the other 2 study areas. Polychaete densities were always higher in the natural marshes, but the disparity

Table 2. Analysis of variance results testing for an effect of natural versus transplanted marshes $(1,2 \mathrm{df})$. Mean values from each of the 6 marshes were used as observations in these analyses; diversity is the total no. of taxa within the macrofauna and infauna identified at a marsh. The block effect is not shown. A log transformation was applied to animal densities, and a square-root transformation was used on above-ground biomass

\begin{tabular}{|lccl|}
\hline Observation & $\begin{array}{c}\text { Sum of } \\
\text { Squares }\end{array}$ & $F$ & $p$ \\
\hline Animal densities & & & \\
All large macrofauna & 1.658 & 232.9 & 0.004 \\
$\quad$ Fish & 0.169 & 3.95 & 0.18 \\
$\quad$ Decapod crustacea & 3.353 & 315.3 & 0.003 \\
All infauna & 0.750 & 1.37 & 0.36 \\
$\quad$ Polychaetes & 0.384 & 0.83 & 0.46 \\
$\quad$ Amphipods & 1.054 & 10.86 & 0.081 \\
Macrofauna diversity & 16.67 & 3.57 & 0.20 \\
Infauna diversity & 60.17 & 22.56 & 0.042 \\
Sediment MOM & 21.44 & 80.26 & 0.012 \\
Spartina alterniflora & & & \\
Above-ground biomass & 0.501 & 3.62 & 0.20 \\
Stem density & 43810 & 28.3 & 0.033 \\
\hline
\end{tabular}


between the natural and transplanted marshes varied among the study areas, and the difference was not significant in the ANOVA (Table 2). The difference between the natural and transplanted marshes in polychaete densities decreased with the age of the transplanted marsh (Table 3). At Chocolate Bay and East Matagorda Bay, polychaete populations were dominated by the subsurface deposit feeder Capitella capit- ata and the surface feeder Streblospio benedicti, and their mean densities were highest in natural marshes. The number of polychaete species collected was greatest in the marshes of the Stedman Island study area (Table 3). In addition to $C$. capitata and $S$. benedicti, Brania clavata, Mediomastus californiensis, and Prionospio heterbranchia were also abundant. Most of the dominant polychaetes at Stedman Island were

Table 3. Common benthic infauna from sediment cores collected in 3 transplanted sait marshes and adjacent natural marshes along the Texas coast. Mean densities and standard errors (untransformed data) are from 4 cores collected in each marsh. Core size was $78.5 \mathrm{~cm}^{2}$, and only animals with a mean density over 1.0 in a marsh are listed. Within groups, taxa are ranked by total numerical abundance in samples

\begin{tabular}{|c|c|c|c|c|c|c|c|c|c|c|c|c|}
\hline \multirow{3}{*}{ Infauna } & \multicolumn{4}{|c|}{ East Matagorda Bay } & \multicolumn{4}{|c|}{ Chocolate Bay } & \multicolumn{4}{|c|}{ Stedman Island } \\
\hline & \multicolumn{2}{|c|}{ Natural } & \multicolumn{2}{|c|}{ Transplant } & \multicolumn{2}{|c|}{ Natural } & \multicolumn{2}{|c|}{ Transplant } & \multicolumn{2}{|c|}{ Natural } & \multicolumn{2}{|c|}{ Transplant } \\
\hline & Mean & $\mathrm{SE}$ & Mean & $\mathrm{SE}$ & Mean & $\mathrm{SE}$ & Mean & $\mathrm{SE}$ & Mean & $\mathrm{SE}$ & Mean & $S E$ \\
\hline Polychaeta & 67.0 & 8.29 & 12.8 & 2.25 & 206.5 & 70.12 & 178.0 & 34.12 & 164.5 & 43.87 & 162.0 & 24.98 \\
\hline Streblospio benedicti & 25.3 & 1.84 & 0.5 & 0.50 & 83.8 & 42.85 & 63.8 & 27.70 & 24.5 & 8.45 & 32.8 & 7.41 \\
\hline Capitella capitata & 24.0 & 6.39 & 9.5 & 1.94 & 80.3 & 26.63 & 66.8 & 16.85 & 24.5 & 8.11 & 23.3 & 6.14 \\
\hline Brania cf. clavata & 0.0 & 0.00 & 0.0 & 0.00 & 0.0 & 0.00 & 0.0 & 0.00 & 51.5 & 14.52 & 75.8 & 21.46 \\
\hline Polydora spp. & 0.0 & 0.00 & 0.0 & 0.00 & 16.8 & 10.16 & 22.8 & 6.45 & 3.0 & 0.71 & 3.5 & 2.60 \\
\hline Heteromastis filiformis & 4.8 & 2.95 & 0.3 & 0.25 & 8.8 & 4.84 & 20.0 & 9.06 & 3.0 & 1.47 & 1.5 & 0.87 \\
\hline Nereis (Neanthes) succined & 12.8 & 1.25 & 2.0 & 0.71 & 7.0 & 2.04 & 4.0 & 0.91 & 2.5 & 1.50 & 1.8 & 0.63 \\
\hline Mediomastus californiensis & 0.0 & 0.00 & 0.0 & 0.00 & 0.0 & 0.00 & 0.0 & 0.00 & 29.0 & 26.35 & 0.0 & 0.00 \\
\hline Prionospio heterbranchia & 0.0 & 0.00 & 0.0 & 0.00 & 0.0 & 0.00 & 0.0 & 0.00 & 12.3 & 2.29 & 14.5 & 7.62 \\
\hline Polydora ligni & 0.0 & 0.00 & 0.0 & 0.00 & 7.0 & 7.00 & 0.0 & 0.00 & 0.0 & 0.00 & 0.0 & 0.00 \\
\hline Sabella micropthalma & 0.0 & 0.00 & 0.0 & 0.00 & 0.0 & 0.00 & 0.0 & 0,00 & 4.8 & 3.54 & 0.8 & 0.48 \\
\hline Spirorbidae & 0.0 & 0.00 & 0.0 & 0.00 & 0.0 & 0.00 & 0.0 & 0.00 & 0.0 & 0.00 & 4.5 & 4.50 \\
\hline Sabella spp. & 0.0 & 0.00 & 0.0 & 0.00 & 0.0 & 0.00 & 0.0 & 0.00 & 3.0 & 2.38 & 0.0 & 0.00 \\
\hline Fabriciola trilobata & 0.0 & 0.00 & 0.0 & 0.00 & 0.0 & 0.00 & 0.0 & 0.00 & 1.5 & 1.50 & 0.0 & 0.00 \\
\hline Oligochaeta & 19.8 & 8.83 & 0.0 & 0.00 & 23.3 & 11.63 & 120.0 & 48.44 & 59.5 & 44.71 & 16.0 & 2.12 \\
\hline Amphipoda & 2.3 & 1.93 & 0.5 & 0.29 & 221.5 & 53.06 & 89.0 & 41.12 & 68.5 & 19.89 & 22.0 & 4.65 \\
\hline Gammarus mucronatus & 2.0 & 2.00 & 0.5 & 0.29 & 138.3 & 58.91 & 53.5 & 26.43 & 5.8 & 2.95 & 9.3 & 2.56 \\
\hline Corophium spp. & 0.0 & 0.00 & 0.0 & 0.00 & 74.8 & 28.37 & 30.0 & 15.38 & 1.0 & 0.58 & 4.0 & 2.16 \\
\hline Grandidierella bonneroides & 0.0 & 0.00 & 0.0 & 0.00 & 8.5 & 3.28 & 5.5 & 3.01 & 9.5 & 2.90 & 3.5 & 0.50 \\
\hline Cymadusa compta & 0.0 & 0.00 & 0.0 & 0.00 & 0.0 & 0.00 & 0.0 & 0.00 & 18.5 & 7.50 & 1.5 & 0.65 \\
\hline Caprellidea & 0.0 & 0.00 & 0.0 & 0.00 & 0.0 & 0.00 & 0.0 & 0.00 & 14.0 & 4.83 & 0.3 & 0.25 \\
\hline Elasmopus cf. levis & 0.0 & 0.00 & 0.0 & 0.00 & 0.0 & 0.00 & 0.0 & 0.00 & 9.8 & 4.68 & 0.0 & 0.00 \\
\hline Ampelisca abdita & 0.0 & 0.00 & 0.0 & 0.00 & 0.0 & 0.00 & 0.0 & 0.00 & 5.0 & 1.96 & 3.5 & 1.94 \\
\hline Melita spp. & 0.0 & 0.00 & 0.0 & 0.00 & 0.0 & 0.00 & 0.0 & 0.00 & 2.5 & 1.89 & 0.0 & 0.00 \\
\hline \multicolumn{13}{|l|}{ Tanaidacea } \\
\hline Hargeria rapax & 0.8 & 0.48 & 0.0 & 0.00 & 41.3 & 28.57 & 1.3 & 0.95 & 21.3 & 3.68 & 41.0 & 14.82 \\
\hline \multicolumn{13}{|l|}{ Isopoda } \\
\hline Cassidinidea ovalis & 0.0 & 0.00 & 0.0 & 0.00 & 6.3 & 2.84 & 0.0 & 0.00 & 1.5 & 0.87 & 0.5 & 0.50 \\
\hline Edotea montosa & 0.0 & 0.00 & 0.0 & 0.00 & 0.3 & 0.25 & 0.8 & 0.48 & 0.3 & 0.25 & 4.0 & 1.87 \\
\hline \multicolumn{13}{|l|}{ Mollusca } \\
\hline Bivalve & 0.0 & 0.00 & 0.0 & 0.00 & 1.3 & 0.48 & 4.0 & 1.35 & 2.0 & 0.82 & 0.8 & 0.75 \\
\hline Gastropod & 0.0 & 0.00 & 0.0 & 0.00 & 0.0 & 0.00 & 0.3 & 0.25 & 4.0 & 2.38 & 2.5 & 1.04 \\
\hline \multicolumn{13}{|l|}{ Other } \\
\hline Nematoda & 2.5 & 1.19 & 0.0 & 0.00 & 36.5 & 18.56 & 33.5 & 13.60 & 20.8 & 8.17 & 27.0 & 11.55 \\
\hline Nemertea & 0.0 & 0.00 & 0.0 & 0.00 & 0.0 & 0.00 & 0.0 & 0.00 & 5.3 & 1.93 & 2.3 & 0.48 \\
\hline Copepoda & 3.5 & 1.44 & 0.0 & 0.00 & 0.3 & 0.25 & 0.0 & 0.00 & 0.3 & 0.25 & 1.3 & 0.63 \\
\hline Pycnogonida & 0.0 & 0.00 & 0.0 & 0.00 & 0.0 & 0.00 & 0.0 & 0.00 & 4.8 & 2.87 & 0.0 & 0.00 \\
\hline
\end{tabular}




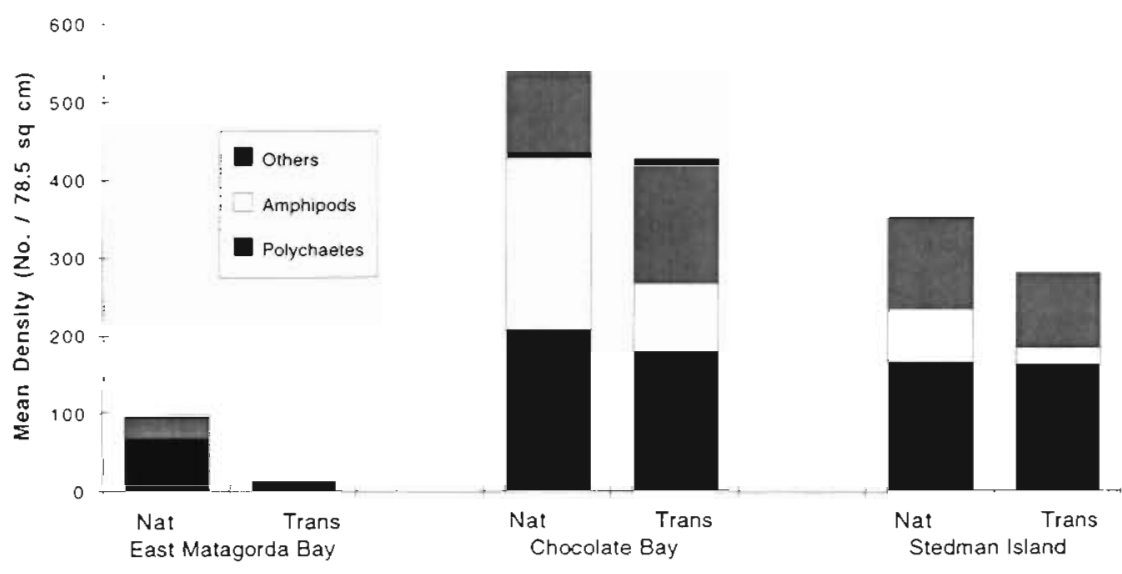

Fig. 2. Densities of infauna from $78.5 \mathrm{~cm}^{2}$ sediment cores collected in natural and transplanted marshes. Mean values presented are from 4 cores collected at each marsh
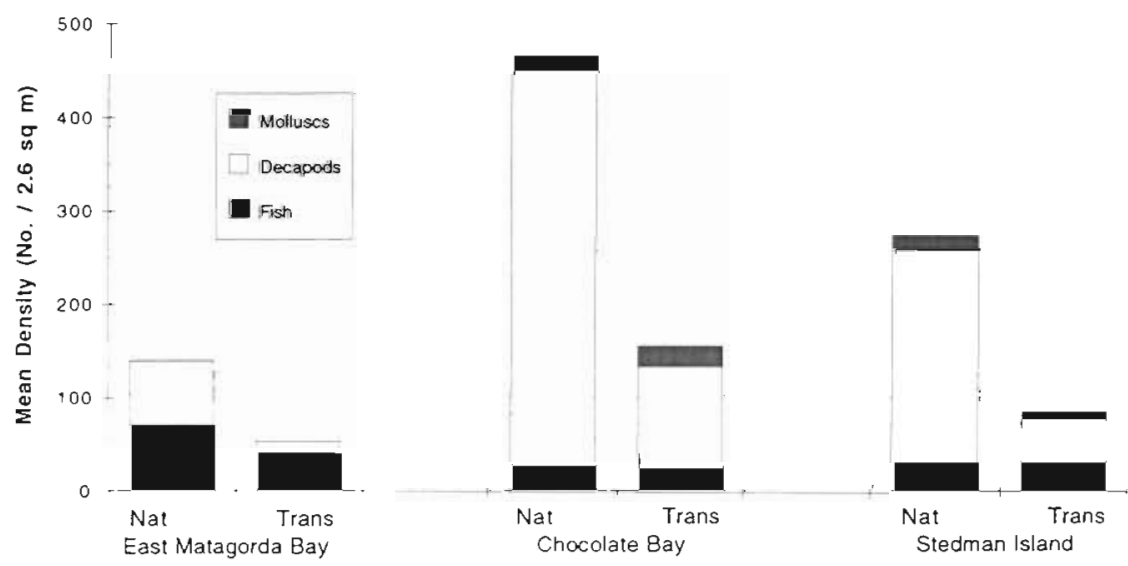

Fig. 3. Densities of large macrofauna from $2.6 \mathrm{~m}^{2}$ drop samples collected in natural and transplanted marshes. Mean values presented are from 4 samples collected at each marsh

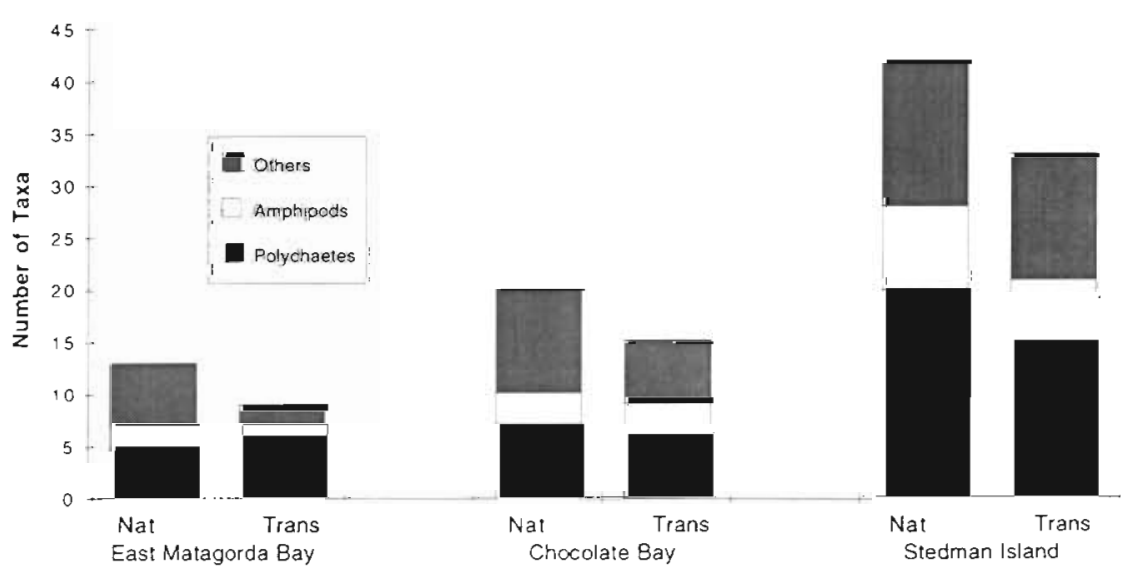

Fig. 4. Diversity of benthic inf a una from sediment cores collected in natural and transplanted marshes. Diversity for each salt marsh is defined as the no. of taxa identified from four $10 \mathrm{~cm}$ diameter cores (total area of $314 \mathrm{~cm}^{2}$ ) found in similar densities between the natural and transplanted marshes; $M$. californiensis, however, was found only in the natural marsh. Oligochaetes were generally less abundant than polychaetes, and there was no consistent difference between natural and transplanted marshes for this group of annelids.

Amphipods were abundant in the cores from the Chocolate Bay and Stedman Island study areas but were present only in low numbers at East Matagorda Bay. Mean densities were consistently lower in the transplanted marshes (Table 3), and the ANOVA approached statistical significance $(p=0.081$, Table 2). Dominant species varied among the study areas, but Gammarus mucronatus and Corophium spp. were most abundant overall. The tanaid Hargeria rapax was also abundant but did not exhibit any consistent differences between natural and transplanted marshes (Table 3).

Most of the large macrofauna collected in the drop samples consisted of fish and decapod crustaceans (Fig. 3). The mean densities of large macrofauna overall and of decapod crustaceans were significantly higher in the natural marshes (Table 2). Daggerblade grass shrimp Palaemonetes pugio and young brown shrimp Penaeus aztecus were the dominant decapods in the marshes, and these, along with most other decapod species, were consistently more abundant in natural marshes (Table 4). Juvenile blue crabs Callinectes sapidus were the exception and were found in similar or higher densities in the transplanted marshes compared to the natural marshes. The density of fish as a group was not significantly different between the 
natural and transplanted marshes (Table 2). Fish species varied with marsh location, but overall the darter goby Gobionellus boleosoma and pinfish Lagodon rhomboides were most abundant (Table 4).

Taxonomic diversity within the infauna was significantly greater in natural marshes (Table 2), and among study areas, was highest at Stedman Island and lowest at East Matagorda Bay (Fig. 4). Diversity of large macrofauna was not significantly different between transplanted and natural marshes (Table 2, Fig. 5), but transplanted marshes generally had fewer decapod species and more fish species than natural marshes. Overall, 7 decapod species were identified from transplanted marshes and 15 species from natural marshes.
Simple linear correlations were used to examine relationships among marsh characteristics. Aboveground Spartina alterniflora structure (biomass and stem density) was not significantly correlated with densities of infauna, decapod crustaceans, or fish (all p's >0.09), but all coefficients were negative. In contrast, densities of infauna (Fig. 6) and decapod crustaceans were positively correlated with sediment MOM (infauna, $r=0.56, \mathrm{p}=0.005, \mathrm{n}=23$; decapods, $r=0.65, p<0.001, n=23)$. In subsets of the data, these correlations were significant in the transplanted marshes (infauna, $\mathrm{r}=0.88, \mathrm{p}<0.001, \mathrm{n}=12$; decapods, $r=0.72, p=0.009, n=12$ ) but not in the natural marshes (all p's $>0.10, \mathrm{n}=11$ ). Fish densities were

Table 4. Common large macrofauna in 3 transplanted salt marshes and adjacent natural marshes along the Texas Coast. Mean densities and standard errors (untransformed data) are from 4 drop samples collected in each marsh. Sample size was $2.6 \mathrm{~m}^{2}$, and only animals with a mean density over 1.0 in a marsh are listed. Within groups, species are ranked by total abundance in samples. Mean total length or carapace width $(\mathrm{mm})$ is given in parentheses for selected crustaceans

\begin{tabular}{|c|c|c|c|c|c|c|c|c|c|c|c|c|}
\hline & \multicolumn{4}{|c|}{ East Matagorda Bay } & \multicolumn{4}{|c|}{ Chocolate Bay } & \multicolumn{4}{|c|}{ Stedman Island } \\
\hline & \multicolumn{2}{|c|}{ Natural } & \multicolumn{2}{|c|}{ Transplant } & \multicolumn{2}{|c|}{ Natural } & \multicolumn{2}{|c|}{ Transplant } & \multicolumn{2}{|c|}{ Natural } & \multicolumn{2}{|c|}{ Transplant } \\
\hline & Mean & SE & Mean & SE & Mean & $\mathrm{SE}$ & Mean & SE & Mean & $\mathrm{SE}$ & Mean & $\mathrm{SE}$ \\
\hline Fishes & 70.5 & 24.65 & 40.0 & 10.75 & 26.5 & 3.66 & 23.5 & 11.98 & 30.5 & 5.24 & 30.8 & 6.14 \\
\hline Gobionellus boleosoma & 63.8 & 20.99 & 32.3 & 7.44 & 3.8 & 1.55 & 3.0 & 0.91 & 15.8 & 4.17 & 6.8 & 2.95 \\
\hline Lagodon rhomboides & 0.5 & 0.50 & 0.5 & 0.50 & 20.0 & 3.24 & 5.5 & 2.33 & 11.3 & 5.62 & 9.8 & 1.11 \\
\hline Leiostomus xanthurus & 0.0 & 0.00 & 4.8 & 4.09 & 0.0 & 0.00 & 7.5 & 6.54 & 0.0 & 0.00 & 0.3 & 0.25 \\
\hline Adinia xenica & 0.0 & 0.00 & 0.5 & 0.50 & 0.0 & 0.00 & 0.0 & 0.00 & 1.5 & 1.50 & 5.8 & 3.38 \\
\hline Cyprinodon variegatus & 5.0 & 4.67 & 1.0 & 1.00 & 0.3 & 0.25 & 0.0 & 0.00 & 0.0 & 0.00 & 0.0 & 0.00 \\
\hline Lucania parva & 0.0 & 0.00 & 0.0 & 0.00 & 0.0 & 0.00 & 0.0 & 0.00 & 0.0 & 0.00 & 6.3 & 4.73 \\
\hline Fundulus grandis & 0.5 & 0.29 & 0.0 & 0.00 & 2.0 & 0.82 & 2.8 & 1.31 & 0.3 & 0.25 & 0.5 & 0.50 \\
\hline Fundulus similis & 0.0 & 0.00 & 0.0 & 0.00 & 0.3 & 0.25 & 3.0 & 1.91 & 0.0 & 0.0 & 0.3 & 0.25 \\
\hline Crustaceans & 68.8 & 24.21 & 13.8 & 5.86 & 423.8 & 117.89 & 110.8 & 29.86 & 227.5 & 63.87 & 46.8 & 3.42 \\
\hline Palaemonetes pugio & 15.3 & 10.18 & 3.5 & 3.18 & 348.5 & 125.18 & 66.5 & 25.04 & 132.5 & 46.39 & 17.8 & 3.57 \\
\hline Penaeus aztecus & 31.0 & 15.85 & 4.0 & 2.00 & 54.8 & 13.98 & 22.3 & 5.68 & 22.3 & 3.52 & 14.8 & 3.07 \\
\hline Callinectes sapidus & 7.0 & 1.29 & 6.0 & 2.27 & 12.0 & 1.29 & 19.5 & 5.84 & 4.3 & 1.84 & 10.5 & 1.85 \\
\hline Palaemonetes intermedius & 0.0 & 0.00 & 0.0 & 0.00 & 0.8 & 0.75 & 0.8 & 0.75 & 36.8 & 4.17 & 1.5 & 0.65 \\
\hline Clibanarius vittatus & 5.8 & 3.77 & 0.0 & 0.00 & 7.8 & 3.30 & 1.8 & 1.18 & 0.5 & 0.29 & 1.8 & 0.85 \\
\hline Alpheus heterochaelis & 0.5 & 0.29 & 0.0 & 0.00 & 0.0 & 0.00 & 0.0 & 0.00 & 7.3 & 4.75 & 0.5 & 0.29 \\
\hline Uca longisignalis & 5.3 & 3.09 & 0.0 & 0.00 & 0.0 & 0.00 & 0.0 & 0.00 & 0.0 & 0.00 & 0.0 & 0.00 \\
\hline Palaemonetes vulgaris & 0.0 & 0.00 & 0.3 & 0.25 & 0.0 & 0.00 & 0.0 & 0.00 & 3.8 & 2.39 & 0.0 & 0.00 \\
\hline Sesarma reticulatum & 3.0 & 1.08 & 0.0 & 0.00 & 0.0 & 0.00 & 0.0 & 0.00 & 0.0 & 0.00 & 0.0 & 0.00 \\
\hline Penaeus setiferus & 0.8 & 0.75 & 0.0 & 0.00 & 0.0 & 0.00 & 0.0 & 0.00 & 1.5 & 1.50 & 0.0 & 0.00 \\
\hline Panopeus turgidus & 0.0 & 0.00 & 0.0 & 0.00 & 0.0 & 0.00 & 0.0 & 0.00 & 2.0 & 1.68 & 0.0 & 0.00 \\
\hline Panopeus herbstii & 0.3 & 0.25 & 0.0 & 0.00 & 0.0 & 0.00 & 0.0 & 0.00 & 1.5 & 1.50 & 0.0 & 0.00 \\
\hline Neopanope texana & 0.0 & 0.00 & 0.0 & 0.00 & 0.0 & 0.00 & 0.0 & 0.00 & 1.5 & 0.96 & 0.0 & 0.00 \\
\hline Hippolyte zostericola & 0.0 & 0.00 & 0.0 & 0.00 & 0.0 & 0.00 & 0.0 & 0.00 & 1.3 & 1.25 & 0.0 & 0.00 \\
\hline Callinectes sapidus & $(21.1)$ & $(4.99)$ & $(19.6)$ & $(6.65)$ & $(15.2)$ & $(1.65)$ & $(14.5)$ & $(1.32)$ & $(42.9)$ & $(13.39)$ & $\{29.2\}$ & $(1.48)$ \\
\hline Palaemonetes pugio & $(28.8)$ & $(0.65)$ & $(23.9)$ & $(0.85)$ & $(27.2)$ & $(0.51)$ & $(29.1)$ & $(0.63)$ & $(24.6)$ & $(1.78)$ & $(26.4)$ & $(0.31)$ \\
\hline Penaeus aztecus & $(14.8)$ & $(1.18)$ & $(12.7)$ & $(1.18)$ & (15.4) & $(0.41)$ & $(16.9)$ & $(1.38)$ & $(43.2)$ & $(6.48)$ & $(38.6)$ & $(4.68)$ \\
\hline Molluscs & 0.8 & 0.75 & 0.0 & 0.00 & 15.8 & 6.75 & 21.8 & 10.96 & 15.8 & 11.82 & 7.8 & 5.92 \\
\hline Littorina irrorata & 0.8 & 0.75 & 0.0 & 0.00 & 6.3 & 1.75 & 21.8 & 10.96 & 0.3 & 0.25 & 4.3 & 3.07 \\
\hline Crassostrea virginica & 0.0 & 0.00 & 0.0 & 0.00 & 8.3 & 8.25 & 0.0 & 0.00 & 12.5 & 12.50 & 0.0 & 0.00 \\
\hline Neritina virginea & 0.0 & 0.00 & 0.0 & 0.00 & 0.0 & 0.00 & 0.0 & 0.00 & 0.0 & 0.00 & 2.5 & 2.50 \\
\hline Thais haemastoma & 0.0 & 0.00 & 0.0 & 0.00 & 0.0 & 0.00 & 0.0 & 0.00 & 2.3 & 2.25 & 0.0 & 0.00 \\
\hline Melampus bidentatus & 0.0 & 0.00 & 0.0 & 0.00 & 1.3 & 1.25 & 0.0 & 0.00 & 0.0 & 0.00 & 0.0 & 0.00 \\
\hline
\end{tabular}




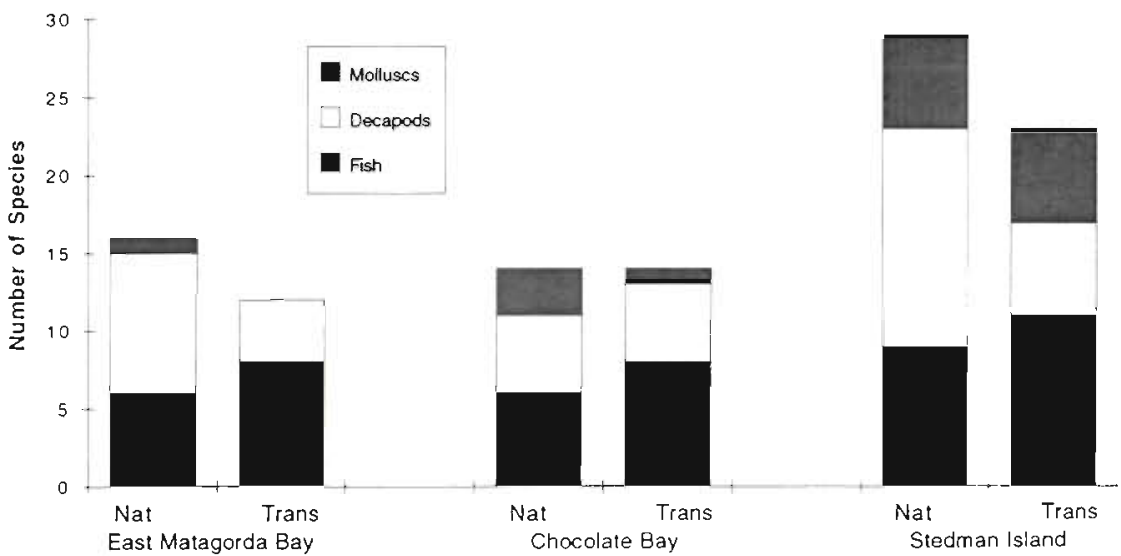

Fig. 5. Diversity of large macrofauna in the natural and transplanted salt marshes. Diversity for each marsh is defined as the no. of species identified from 4 drop samples (total area of $10.4 \mathrm{~m}^{2}$ )

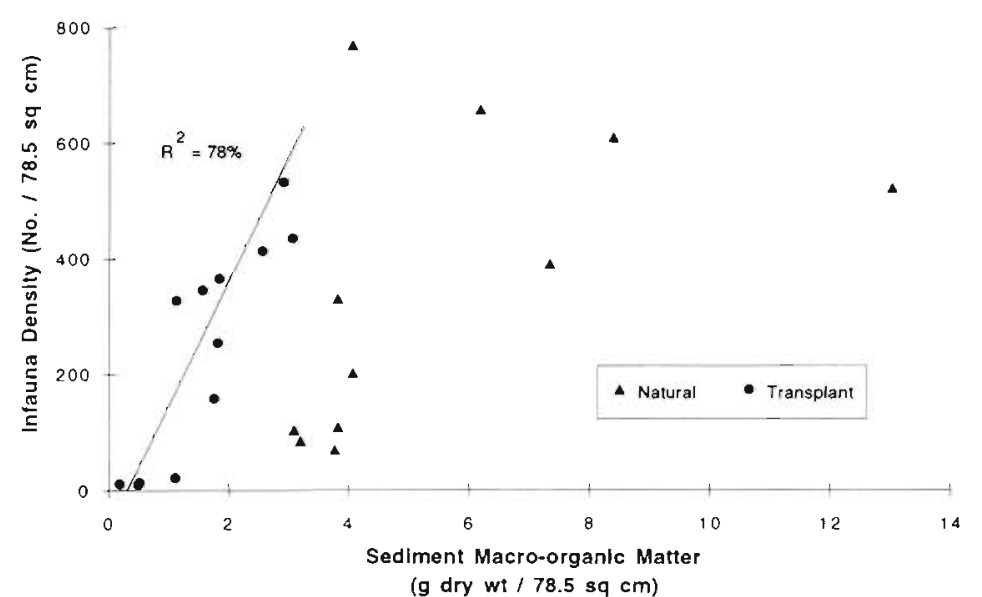

Fig. 6. Relationship between density of infauna and the dry weight of macro-organic matter in the upper $5 \mathrm{~cm}$ of sediment cores. The significant regression line is based on the data from only the transplanted marshes

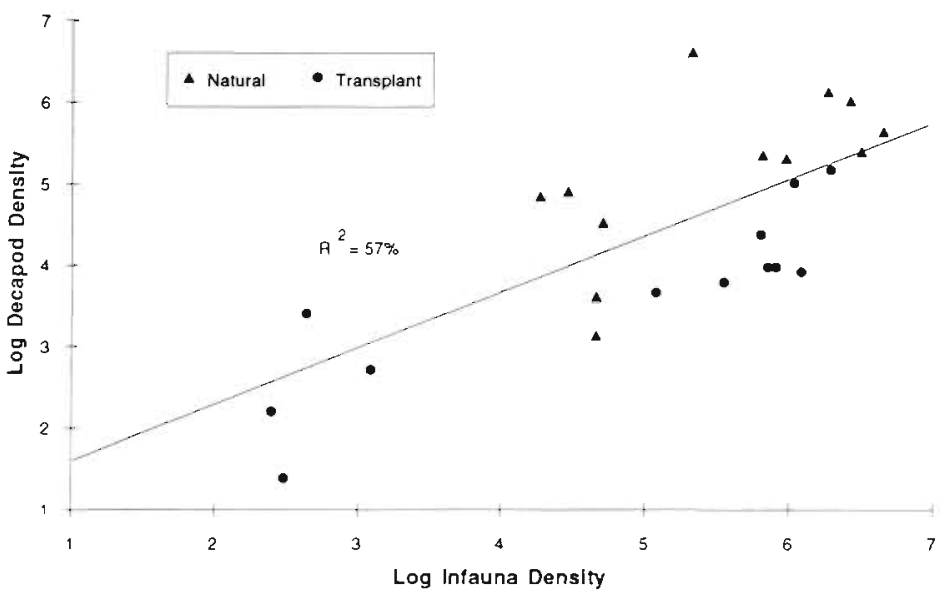

Fig. 7 Relationship between log-transformed densities of decapod crustaceans in d-op samples (2.6 $\mathrm{m}^{2}$ area) and log-transformed densities of infauna in associated sediment cores $\left(78.5 \mathrm{~cm}^{2}\right.$ area). The significant regression line shown is based on data from both the natural and transplanted marshes not correlated with MOM $(\mathrm{r}=-0.01, \mathrm{p}=0.95, \mathrm{n}=23)$. Overall, densities of infauna were positively correlated with densities of decapod crustaceans $(\mathrm{r}=0.45, \mathrm{p}=0.028, \mathrm{n}=24)$. This relationship was stronger when densities were log transformed ( $\mathrm{r}=0.76, \mathrm{p}<0.001, \mathrm{n}=24$ ) and was significant in both natural and transplanted marshes (Fig. 7). Densities of infauna and fish were not significantly correlated $(\mathrm{r}=-0.30, \mathrm{p}=0.16$, $\mathrm{n}=24$ ).

\section{DISCUSSION}

Above-ground growth of Spartina alterniflora appeared vigorous in the transplanted marshes, as evidenced by consistently higher biomass and stem density compared with nearby natural marshes. In the northern Gulf of Mexico, $S$. alterniflora is growing actively during the spring, with peak live biomass and stem density occurring in the late summer and fall (Hopkinson et al. 1978, Sears 1981, Kaswadji et al. 1990). Differences in aboveground biomass between natural and transplanted marshes appeared to decline with the age of the transplanted marsh. Similar relationships between natural and transplanted marshes have been observed along the coasts of both the Gulf of Mexico by Webb et al. (1978) and Webb \& Newling (1985) and the Atlantic by Cammen (1975), Seneca et al. (1985), Broome et al. (1986), Broome (1989), and LaSalle et al. (1991). Sediment macro-organic matter (weight of roots, rhizomes, and detritus in the upper $5 \mathrm{~cm}$ ) was significantly lower in the transplanted marshes compared with the natural marshes. Low below-ground root biomass and sediment organic content have been observed in other transplanted marshes (Cammen 1975. Webb et al. 1978, Lindau \& Hossner 1981, Craft et al. 1988. Sacco 1989, Langis et al. 1991, LaSalle et al. 1991, Moy \& Levin 1991).

The overall low density of infauna in our transplanted marshes was consistent with general trends shown by Cammen (1976), Sacco (1989), and Moy \& Levin (1991) in marshes along the southern Atlantic coast. We also found that diversity of these animals 
was significantly lower in the transplanted marshes. Mean amphipod densities in transplanted marshes were only 22 to $40 \%$ of densities in natural marshes, and the difference approached statistical significance. Most amphipod species followed the abundance trend for amphipods as a group. Although polychaete densities were not significantly different between the natural and transplanted marshes, there was some indication that the abundance of this group was related to the age of the marsh; differences from natural marshes were greatest for the youngest transplanted marsh (East Matagorda Bay) and smallest for the oldest transplanted marsh (Stedman Island). LaSalle et al. (1991) also reported a positive relationship between the density of benthic infauna and marsh age. Moy \& Levin (1991) found the ratio of polychaetes to oligochaetes was higher in their transplanted marsh compared with a natural marsh; this observation is important because polychaetes were more accessible as prey for marsh predators. In our marshes, however, there was no consistent difference between natural and transplanted marshes in the ratio of polychaetes to oligochaetes. In summarizing comparisons of infaunal populations, Sacco (1989) suggested that the inconsistency in differences between natural and created marshes was due to local conditions that affected, among other things, the accumulation of soil organic matter. In our transplanted marshes there was a strong correlation between the abundance of infauna and the amount of macro-organic matter in the sediment.

The drop sampler used in our study provides quantitative samples of natant macrofauna within vegetation (Zimmerman et al. 1984, 1986) allowing a direct measure of marsh utilization. Densities of all large macrofauna and the decapod crustaceans were significantly lower in the transplanted marshes compared with the natural marshes, and this difference was due mainly to daggerblade grass shrimp and young brown shrimp. Transplanted marshes supported only 30 to $38 \%$ of the large macrofauna and 20 to $26 \%$ of the decapod crustaceans found in natural marshes at the 3 study areas. Most decapod species followed this trend of reduced utilization of the transplanted marshes. A notable exception was the blue crab, and mean densities of juvenile blue crabs were higher in transplanted marshes at 2 of the 3 study areas. Diversity of decapod crustaceans was generally higher in the natural marshes.

Densities of fish as a group were not significantly different between natural and transplanted marshes. The mean fish density was higher at the natural marsh in East Matagorda Bay, but at the other 2 sites, densities were similar between the marsh types. The darter goby and the pinfish were most abundant, making up over $78 \%$ of the fish collected. For other fish species, low densities prevented meaningful comparisons between natural and transplanted marshes. A total of 19 fish species were collected, and diversity was consistently higher in the transplanted marshes.

The role of sediment macro-organic matter in the trophic development of transplanted marshes is suggested by the strong positive correlation between this parameter and the abundance of infauna. The lack of a similar relationship in the natural marshes suggests that other factors regulate infaunal populations once a threshold level of sediment organic biomass is reached. As suggested by Moy \& Levin (1991) and others, the abundance of deposit-feeding organisms may increase with increased below-ground biomass and associated detrital food. Sediment structure provided by roots and rhizomes may also be important in reducing competition within the infauna or reducing foraging efficiency of predators on infauna. Live Spartina alterniflora roots produce micro-oxygenated zones (Teal \& Kanwisher 1966, Armstrong 1979) that could provide additional inhabitable space within marsh sediments (Osenga \& Coull 1983, LaSalle et al. 1991). Another explanation, however, is that development of sediment MOM and below-ground biomass in a transplanted marsh simply coincides with more important processes such as the development of benthic and epiphytic microalgal populations.

Decapod crustaceans feed on benthic infauna and epifauna (Kneib 1985, Leber 1985, Hunter \& Feller 1987, Feller 1991, Minello \& Zimmerman 1991), and seasonal fluctuations in marsh populations suggest a predator-prey relationship (Zimmerman et al. 1991). The correlation between densities of decapods and infauna in our samples may reflect this relationship. Young brown shrimp have been shown to selectively prey on amphipods and polychaetes, apparently fulfilling a requirement for animal food in their diet (Gleason \& Wellington 1988, McTigue \& Zimmerman 1991, reviewed in Minello \& Zimmerman 1991). Thus, low densities of amphipods and polychaetes in transplanted marshes suggest that, for brown shrimp, the short-term food value of these marshes is lower than natural marshes. There is also some evidence that amphipods and polychaetes are selected as prey by Palaemonetes spp. (Nelson 1979, Kneib 1985, Nelson \& Capone 1990), but meiofauna, epiphytic algae, and perhaps detritus appear to be important dietary items as well (Welsh 1975, Bell \& Coull 1978, Morgan 1980). If the development of these food resources in transplanted marshes coincide, infauna populations may be indicators of food value for grass shrimp in salt marshes. Densities of small fish and blue crabs were not correlated with densities of infauna and epifauna, although these predators also feed on polychaetes and peracarid crustaceans (Kjelson et al. 1975, Adams 1976, Nelson 1981, Minello et al. 1989, Thomas 1989). 
Perhaps a wider dietary breadth (Kneib \& Stiven 1978, Kneib 1986, West \& Williams 1986, Lin 1989, Thomas 1989. Rozas \& LaSalle 1990, LaSalle et al. 1991, Minello \& Zimmerman 1991) makes the relationship between the abundance of these predators and their prey more complex.

The relative food value of a salt marsh for transient fish and decapods may be difficult to determine with simple assessments of prey abundance. In some instances, prey standing crop may be misleading as an indicator of food abundance, if productivity and standing crop are not closely related. In addition, microhabitat distributions are important in these predator-prey interactions (Nelson \& Capone 1990). Although Moy \& Levin (1991) found more infauna in their natural marshes, the diets of killifish from the transplanted marsh appeared more nutritious than diets of fish from the natural marshes. They concluded that deep-living infauna, such as oligochaetes, were relatively unavailable as prey; thus, their presence in large numbers would not necessarily indicate high food value for a marsh.

There are a variety of other reasons why the abundance of predators in salt marshes may not coincide with the abundance of prey. In some marshes, physical factors can be important in determining the abundance and distribution of infauna and predators (Van Dolah 1978, Kneib 1982, 1984). Hypoxia, for example, can affect animal distributions, and we have unpublished data showing nighttime hypoxic conditions (dissolved oxygen below 2 ppm) at the Stedman Island transplanted marsh in February 1986. The abundance of small predators may also be controlled by large predators. As an example of the importance of predator size and position in the trophic web, Kneib \& Stiven (1982) and Kneib (1988) described how an extra link in the food web can reverse the population response of infaunal prey to a predator.

The intertidal nature of salt marshes adds a special complexity to predator-prey relationships in these habitats. In marshes where limited tidal flooding and minimal marsh/water edge restrict access to the marsh surface by transient predators, predation pressure on infaunal prey populations will be low. The physical exclusion of natant predators from the marsh can allow infaunal populations to increase (Van Dolah 1978, Kneib \& Stiven 1982). Thus, in marshes where there is evidence of restricted access for predators, high infaunal densities may indicate the marsh has relatively low direct food value. In our comparisons, samples in natural and transplanted marshes were taken at comparable distances from the water's edge. Sample water depths indicated that marsh elevations and tidal flooding patterns were similar within the study areas. Possible differences in flooding patterns among study areas were not examined, but we suspect that the marsh-edge habitat was inundated frequently at all sites.

In addition to supplying food, salt marshes also function to protect decapod crustaceans and small fishes from larger fish predators (Boesch \& Turner 1984, Kneib 1987, Thomas 1989, Minello \& Zimmerman 1991). This protective function is related to the presence of structural cover (Coen et al. 1981, Heck \& Thoman 1981, Lascara 1981, Minello \& Zimmerman 1983, Minello et al. 1989) and shallow water depth (Kneib 1987). These habitat characteristics are quickly acquired in transplanted marshes. Equivalent utilization of natural and transplanted marshes from the outset may indicate that for some animals, such as fishes, the protective function of the marsh is primary. Predation pressure in a habitat, however, is a not merely a function of cover and water depth, but of the number and type of predators present. Food webs varied between our transplanted and natural marshes, as indicated by differences in diversity, thus predation pressures may have differed. Experiments with tethered prey, that provide comparisons of predation pressure among habitats (Heck \& Thoman 1981, Wilson et al. 1990), could supply valuable information on the refuge function of transplanted marshes.

\section{CAUTIONS AND CONCLUSIONS}

Conclusions from this study are limited because sampling was only conducted during the spring of 1 year. The spring season in Texas, however, is an important period of recruitment for young fishes and crustaceans, and some of the largest animal densities recorded in the marsh occur during the spring (Zimmerman \& Minello 1984, Zimmerman et al. 1991). The data presented in this study on densities of natant macrofauna in natural and transplanted Spartina alterniflora marshes represent the only quantitative comparison of this type in the literature. In part, the reason for this paucity is the effort required to collect and analyze such samples. Unfortunately, one trade off in maximizing the number of samples collected within a season is often a reduction in temporal sampling frequency.

Temporal fluctuations in marsh populations are common, especially for natant macrofauna, and a comparison of these same marshes during some other season may have resulted in different conclusions. This data collection and analysis was intended to represent a snapshot of the marshes during the spring season. The treatment comparison between a transplanted and a natural marsh is replicated 3 times, and each of these 3 comparisons were made on $1 \mathrm{~d}$. Blocking in the analysis should remove other temporal effects in addition to 
location effects. This true replication of the treatment in our sampling design allowed us to statistically test the general null hypothesis that transplanted marshes were the same as natural marshes for the parameters we measured in the spring of 1986 . The 3 transplanted marshes were not randomly selected from all transplanted marshes, but we suspect they represented a relatively large proportion of such marshes (2 to $5 \mathrm{yr}$ old) in Texas at the time of sampling. In addition, the marshes were located in 3 different estuarine systems (over a coastline of $270 \mathrm{~km}$ ) with varying watersheds, climatic conditions, and dominant estuarine vegetation. Therefore, conclusions based on significant differences between the transplanted and natural marshes in this study should be robust. Previous studies have often tested, with a great deal of temporal and spatial replication, whether one transplanted marsh was different from one or several natural marshes. Differences detected among marshes in these studies cannot be properly attributed to the transplanted nature of the marsh (Hurlbert 1984). The accumulation of such studies, however, can provide this information, and results of these studies may be amenable to statistical meta-analysis (Mann 1990).

The salt marsh habitat sampled in our study was within a few meters of the marsh edge, thus comparisons do not extend to the value of the interior marsh surface. Marsh-edge habitat is plentiful in the northern Gulf of Mexico (Faller 1979, Browder et al. 1985, 1989. Zimmerman et al. 1984) and is more intensely utilized by estuarine animals than the inner marsh surface (Minello et al. 1991). Efforts to create salt marshes that benefit estuarine organisms in the northern Gulf of Mexico should attempt to replicate habitat with a large amount of edge.

Despite the above limitations, our data provide a valuable comparison of natural and transplanted marshes ( 2 to 5 yr old) during the spring. Transplanted marshes had lower sediment macro-organic matter and densities of decapod crustaceans, and they had higher stem densities of Spartina alterniflora. These differences were significant even though the power of the statistical tests was low. Our results suggest that transplanted marshes can function as natural marshes if given enough time. Although marsh age was confounded with location, there appeared to be a progression of development in the transplanted marshes over a 5 yr period. For some marsh functions, such as protection from predators, transplanted marshes may reach equivalency with natural marshes after 1 or 2 growing seasons, when the amount of above-ground structure is comparable. The development of the feeding function of marshes is probably slower, and may be related in part to the buildup of organic matter in marsh sediments. Densities of decapod crustaceans in the transplanted marshes we examined appeared to be linked to densities of infaunal prey and the amount of sediment macro-organic matter. The development rate for this function probably varies with specific local conditions, but the oldest marsh in our study ( 5 yr) did not appear to have reached equivalency in providing food.

Acknowledgements. This research was supported by the Southeast Fisheries Science Center of the National Marine Fisheries Service and in particular by Edward Klima, the director of the Galveston Laboratory. Marie Pattıllo, Tim Baumer, and Richard Pratt sorted and identified samples and conducted some preliminary data analysis. Helpful comments on the manuscript were provided by R. Lewis, W. Richards, L. Rozas and 2 anonymous reviewers.

\section{LITERATURE CITED}

Adams, S. M. (1976). Feeding ecology of eelgrass fish communities. Trans. Am. Fish. Soc. 105: 514-19

Armstrong, W. (1979). Aeration in higher plants. Adv. Bot. Res. 7: 225-332

Baltz, D. M., Rakocinski, C., Fleeger, J W. (1992). Microhabitat use by marsh-edge fishes in a Louisiana estuary. Environ. Biol. Fishes (in press)

Bell, S. S., Coull, B. C. (1978). Field evidence that shrimp predation regulates meiofauna. Oecologia 35: 141-148

Boesch, D. F., Turner, R. E. (1984). Dependence of fishery species on salt marshes: the role of food and refuge. Estuaries 7: $460-468$

Broome, S. W. (1989). Creation and restoration of tidal wetlands of the Southeastern United States. In: Kusler, J. A., Kentula, M. E. (eds.). Wetland creation and restoration: the status of the science. Vol. I. Regional overviews. EPA/600/3-89/038. U.S. Environmental Protection Agency, Corvallis, p. 37-72

Broome, S. W., Seneca, E. D., Woodhouse, W. W. (1986) Longterm growth and development of transplants of the saltmarsh grass Spartina alterniflora. Estuaries 9: 63-74

Broome, S. W., Seneca, E. D., Woodhouse, W. W. (1988). Tidal salt marsh restoration. Aquat. Bot. 32: 1-22

Browder, J. A., Bartley, H. A., Davis, K. S. (1985). A probabilistic model of the relationship between marshland-water interface and marsh disintegration. Ecol. Model. 29: $245-260$

Browder, J. A., May, L. N., Rosenthal, A., Gosselink, J. G., Baumann, R. H. (1989). Modeling future trends in wetland loss and brown shrimp production in Louisiana using thematic mapper imagery. Remote Sens. Environ. 28: 45-59

Cammen, L. M. (1975). Accumulation rate and turnover time of organic carbon in a salt marsh sediment. Limnol. Oceanogr. 20: 1012-1015

Cammen, L. M. (1976). Macroinvertebrate colonization of Spartina marshes artificially established on dredge spoil. Estuar. coast. mar. Sci. 4: 357-372

Childers, D. L., Day, J. W., Muller, R. A. (1990). Relating climatological forcing to coastal water levels in Louisiana estuaries and the potential importance of El Niño-Southern Oscillation events. Clim. Res. 1: 31-42

Climatological Data, Annual Summary, Texas. (1990). Report from NOAA's National Climatic Data Center, Asheville, North Carolina. Vol. 95 , no. 13

Coen, L. D., Heck, K. L., Abele, L. G. (1981). Experiments on competition and predation among shrimps of seagrass meadows. Ecology 62: 1484-93 
Craft, C. B., Broome, S. W., Seneca, E. D. (1988). Nitrogen, phosphorus and organic carbon pools in natural and transplanted marsh soils. Estuaries 11: 272-280

Faller, K. H. (1979). Shoreline as a controlling factor in commercial shrimp production. NASA Tech. Memor. NASA. TM-72-732

Feijtel, T C., DeLaune, R. D., Patrick, W. H. (1985). Carbon flow in coastal Louisiana. Mar. Ecol. Prog. Ser. 24: 255-60

Feller, R. J. (1991). Dietary analysis of penaeid shrimp: the immunoassay approach. In: DeLoach, P., Dougherty, W. J., Davidson, M. A. (eds.). Frontiers in shrimp research. Elsevier Sci. Publ., Amsterdam, p. 141-156

Gleason, D. F., Wellington, G. M. (1988). Food resources of postlarval brown shrimp (Penaeus aztecus) in a Texas salt marsh. Mar. Biol. 97: 329-337

Haines, E. B. (1979). Interactions between Georgia salt marshes and coastal waters: a changing paradigm. In Livingston, R. J. (ed.). Ecological processes in coastal and marine systems. Plenum Publishing Corp., New York, p. $35-46$

Heck, K. L., Thoman, T A. (1981). Experiments on predatorprey interactions in vegetated aquatic habitats. J. exp mar. Biol. Ecol. 53: 125-134

Hicks, C. R. (1973). Fundamental concepts in the design of experiments, 2nd edn. Holt, Rinehart and Winston, New York

Hopkinson, C. S., Gosselink, J. G., Parrondo, R. T (1978). Aboveground production of seven marsh plant species in coastal Louisiana. Ecology 59: 760-769

Hunter, J., Feller, R. J. (1987). Immunological dietary analysis of two penaeid shrimp species from a south Carolina tidal creek. J. exp. mar. Biol. Ecol. 107: 61-70

Hurlbert, S. H. (1984). Pseudoreplication and the design of ecological field experiments. Ecol. Monogr. 54: 187-211

Kaswadji, R. F., Gosselink, J. G., Turner, R. E. (1990). Estimation of primary production using five different methods in a Spartina alterniflora salt marsh. Wetld Ecol. Manage. 1: $57-64$

Kjelson, M. A., Peters, D. S., Thayer, G. W., Johnson, G. N (1975). The general feeding ecology of postlarval fishes in the Newport river estuary. Fish. Bull. U.S. 73: 137-144

Kneib, R. T. (1982). Habitat preference, predation, and the intertidal distribution of gammaridean amphipods in a North Carolina salt marsh. J. exp. Mar. Biol. Ecol. 59 $219-30$

Kneib, R. T. (1984). Patterns of invertebrate distribution and abundance in the intertidal salt marsh: causes and questions. Estuaries 7: 392-412

Kneib, R. T. (1985). Predation and disturbance by grass shrimp, Palaemonetes pugio Holthuis, in soft-substratum benthic invertebrate assemblages. J. exp. mar. Biol. Ecol 93: $91-102$

Kneib, R. T (1986). The role of Fundulus heteroclitus in salt marsh trophic dynamics. Am. Zool. 26: 259-69

Kneib, R. T. (1987). Predation risk and use of intertidal habitats by young fishes and shrimp. Ecology 68: 379-86

Kneib, R. T (1988). Testing for indirect effects of predation in an intertidal soft-bottom community. Ecology 69 $1795-1805$

Kneib, R. T., Stiven, A. E. (1978). Growth, reproduction, and feeding of Fundulus heteroclitus (L.) on a North Carolina salt marsh. J. exp. mar. Biol Ecol. 31. 121-140

Kneib, R. T., Stiven, A. E. (1982). Benthic invertebrate responses to size and density manipulations of the common mummichog, Fundulus heteroclitus, in an intertidal salt marsh. Ecology 63: 1518-1532

Knox, G. A. (1986). Chapter 3. Primary production. In:
Estuarine ecosystems: a systems approach, Vol. 1 CRC Press, Inc., Boca Raton, p. 37-112

Langis, R., Zalejko, M., Zedler, J. B. (1991). Nitrogen assessments in a constructed and a natural salt marsh of San Diego Bay. Ecol. Appl. 1: 40-51

LaSalle, M. W., Landin, M. C., Sims, J. G. (1991). Evaluation of the flora and fauna of a Spartina alterniflora marsh established on dredged material in Winyah Bay, South Carolina. Wetlands 11.191-208

Lascara, J. (1981). Fish predator-prey interactions in areas of eelgrass (Zostera marina). M.A. thesis, College of William and Mary

Leber, K. M. (1985). The influence of predatory decapods, refuge, and microhabitat selection on seagrass communities. Ecology 66: 1951-64

Lin, J. (1989). Influence of location in a salt marsh on survivorship of ribbed mussels. Mar. Ecol. Prog. Ser. 56: 105-110

Lindau, C. W. Hossner, L. R. (1981). Substrate characterization of an experimental marsh and three natural marshes. Soil Sci. Soc. Amer. J. 45: 1171-76

Mann. C. (1990). Meta-analysis in the breech. Science 249 $476-480$

McIvor, C. C., Odum, W. E. (1988). Food, predation risk, and microhabitat selection in a marsh fish assemblage. Ecology 69: 1341-51

McTigue, T. A., Zimmerman, R. J. (1991). Carnivory versus herbivory in juvenile Penaeus setiferus (Linnaeus) and Penaeus aztecus (Ives). J. exp. mar. Biol. Ecol. 15: 1-16

Minello, T. J., Webb, J W., Zimmerman, R. J., Wooten, R. B. Martinez, J. L., Baumer, T. J., Pattillo, M. C. (1991). Habitat availability and utilization by benthos and nekton in Hall's Lake and West Galveston Bay. NOAA Tech. Mem. NMFS-SEFC-275: 37

Minello, T. J., Zimmerman, R. J. (1983). Fish predation on juvenile brown shrimp. Penaeus aztecus Ives: the effect of simulated Spartina structure on predation rates. J. exp. mar. Biol. Ecol. 72: 211-231

Minello, T. J., Zimmerman, R. J. (1991). The role of estuarine habitats in regulating growth and survival of juvenile penaeid shrimp. In: DeLoach, P., Dougherty, W. J., Davidson, M. A. (eds.). Frontiers in shrimp research. Elsevier Sci. Publ., Amsterdam, p. 1-16

Minello, T J., Zimmerman, R. J., Martinez, E. X. (1989). Mortality of young brown shrimp Penaeus aztecus in estuarine nurseries. Trans. Am. Fish. Soc 118: 693-708

Morgan, M. D. (1980). Grazing and predation of the grass shrimp Palaemontes pugio. Limnol. Oceanogr. 25: $896-902$

Moy, L. D., Levin, L. A. (1991). Are Spartina marshes a replaceable resource? A functional approach to evaluation of marsh creation efforts. Estuaries 14:1-16

Nelson, W. G. (1979). Experimental studies of selective predation on amphipods: consequences for amphipod distribution and abundance. J. exp. mar. Biol. Ecol. 38: $225-245$

Nelson, W. G. (1981). Experimental studies of decapod and fish predation on seagrass macrobenthos. Mar. Ecol. Prog. Ser. 5: 141-149

Nelson, W. G., Capone, M. (1990). Experimental studies of predation on polychaetes associated with seagrass beds. Estuaries 13: 51-58

Nixon, S. W. (1980). Between coastal marshes and coastal waters-a review of twenty years of speculation and research on the role of salt marshes in estuarine productivity and water chemistry. In: Hamilton, P., Macdonald, K. B. (eds.). Estuarine and wetland processes with emphasis on modeling. Plenum Press, New York, p. 437-524 
Odum, E. P., de la Cruz, A. A. (1967). Particulate organic detritus in a Georgia salt marsh-estuarine ecosystem. In: Lauff, G. H. (ed.) Estuaries. Am. Assoc. Adv. Sci. Publ. 83., Washington, DC, p. 383-388

Osenga, G. A., Coull, B. C. (1983). Spartina alterniflora Loisel root structure and meiofaunal abundance. J. exp. mar. Biol. Ecol. 67: 221-225

Peterson, B. J., Howarth, R. W. (1987). Sulfer, carbon, and nitrogen isotopes used to trace organic matter flow in the salt-marsh estuaries of Sapelo Island, Georgia. Limnol. Oceanogr. 32: 1195-1213

Pomeroy, L. R., Darley, W. M., Dunn, E. L., Gallagher, J. L., Haines, E. B., Whitney, D. M. (1981). Primary production. In: Pomeroy, L. R., Wiegert, R. G. (eds.). The ecology of a salt marsh. Springer-Verlag, New York

Race, M. S., Christie, D. R. (1982). Coastal zone development: mitigation, marsh creation, and decision-making. Environ. Manag. 6: 317-328

Rozas, L. P. (1992). Comparison of nekton habitats associated with pipeline canals and natural channels in Louisiana salt marshes. Wetlands 12: 136-146

Rozas, L. P., LaSalle, M. W. (1990). A comparison of the diets of gulf killifish, Fundulus grandis Baird and Girard, entering and leaving a Mississippi brackish marsh. Estuaries 13: $332-336$

Rozas, L. P., Odum, W. E. (1987). Use of tidal freshwater marshes by fishes and macrofaunal crustaceans along a marsh stream-order gradient. Estuaries 10: 36-43

Sacco, J. (1989). Infaunal community development of artificially established salt marshes in North Carolina. Ph.D. thesis, North Carolina State University, Raleigh

Sasser, C. E. (1977). Distribution of vegetation in Louisiana coastal marshes as reponse to tidal flooding. M.S. thesis, Louisiana State University, Baton Rouge

Sears, N. E. (1981). Studies on the production and decomposition of Spartina alterniflora Loisel. in a Galveston salt marsh. M.S. thesis, Texas A\&M University, College Station

Seneca, E. D., Broome, S. W., Woodhouse, W. W. (1985). The influence of duration-of-inundation on development of a man-initiated Spartina alterniflora Loisel marsh in North Carolina. J. exp. mar. Biol. Ecol. 94: 259-268

Sullivan, M. J., Moncreiff, C. A. (1988). An evaluation of the importance of algae and vascular plants in salt marsh food webs using stable carbon isotope analyses. MississippiAlabama Sea Grant Consortium Publ. MASGP-88-042, Mississippi State

Sullivan, M. J., Moncreiff, C. A. (1990). Edaphic algae are an important component of salt marsh food-webs: evidence from multiple stable isotope analyses. Mar. Ecol. Prog. Ser. 62: $149-159$

Teal, J. M. (1962). Energy flow in the salt marsh ecosystem of Georgia. Ecology 43: 614-24

Teal, J. M., Kanwisher, J. W. (1966). Gas transport in the marsh grass Spartina alterniflora. J. exp. Bot. 17: 355-61

Thomas, J. L. (1989). A comparative evaluation of Halodule wrightii Aschers, Spartina alterniflora Loisel and bare sand as nursery habitats for juvenile Callinectes sapidus (Rathbun). M.S. thesis, Texas A\&M University, College Station

Thomas, J. L., Zimmerman, R. J., Minello, T. J. (1990). Abundance patterns of juvenile blue crabs (Callinectes sapidus) in nursery habitats of two Texas bays. Bull. mar. Sci. 46: $115-125$

Van Dolah, R. F. (1978). Factors regulating the distribution of the amphipod Gammarus palustris in an intertidal salt marsh community. Ecol. Monogr. 48: 191-217

Webb, J. W. (1977). Establishment of vegetation for shoreline stabilization in Galveston Bay, Texas. Ph.D. dissertation, Texas A\&M University, College Station

Webb, J. W., Dodd, J. D., Cain, B. W., Leavens, W. R., Hossner, L. R., Lindau, C., Stickney, R. R., Williamson, H. (1978). Habitat development field investigations, Bolivar Peninsula marsh and upland habitat development site, Galveston Bay, Texas, Appendix D: Propogation of vascular plants and postpropogation of botanical, soil, aquatic biota, and wildlife resources. Tech. Rept. D-78-15. U.S. Army Corps of Engineers, Waterways Experiment Station, Vicksburg, MS

Webb, J. W., Newling, C. J. (1985). Comparison of natural and man-made salt marshes in Galveston Bay complex, Texas. Wetlands 4: 75-86

Weisberg, S. B., Lotrich, V. A. (1982). The importance of an infrequently flooded intertidal salt marsh surface as an energy source for the mummichog Fundulus heteroclitus: an experimental approach. Mar. Biol. 66: 307-310

Weisberg, S. B., Whalen, R., Lotrich, V. A. (1981). Tidal and diurnal influence on food consumption of a salt marsh killifish Fundulus heteroclitus. Mar. Biol. 61: 243-246

Welsh, B. L. (1975). The role of grass shrimp, Palaemonetes pugio, in a tidal marsh system. Ecology 56: 513-30

West, D. L., Williams, H. (1986). Predation by Callinectes sapidus (Rathbun) within Spartina alterniflora (Loisel) marshes. J. exp. mar. Biol. Ecol. 100: 75-95

Wiegert, R. G., Freeman, B. J. (1990). Tidal salt marshes of the southeast Atlantic coast: a community profile. U.S. Fish Wildl. Serv., Biol. Rep. 85 (7.29)

Wilson, K. A., Able, K. W. Heck, K. L. (1990). Predation rates on juvenile blue crabs in estuarine nursery habitats: evidence for the importance of macroalgae (Ulva lactuca). Mar. Ecol. Prog. Ser. 58: 243-251

Woodhouse, W. W. Seneca, E. D., Broome, S. W. (1972). Marsh building with dredge spoil in North Carolina. North Carolina State University Agric. Exp. Sta. Bull. No. 445, Raleigh

Zimmerman, R. J., Minello, T. J. (1984). Densities of Penaeus aztecus, $P$. setiferus and other natant macrofauna in a Texas salt marsh. Estuaries 7: 421-433

Zimmerman, R. J., Minello, T. J., Castiglione, M., Smith, D. (1990a). Utilization of marsh and associated habitats along a salinity gradient in Galveston Bay. NOAA Tech. Mem., NMFS-SEFC-250

Zimmerman, R. J., Minello, T J., Klima, E. F., Nance, J. M. (1991). Effects of accelerated sea-level rise on coastal secondary production. In: Bolton, H. S. (ed.). Coastal wetlands. Amer. Soc. Civil Engineers, New York, p. 110-124

Zimmerman, R. J., Minello, T J., Smith, D., Castiglione, M. (1990b). The use of Juncus and Spartina marshes by fisheries species in Lavaca Bay, Texas, with reference to effects of floods. NOAA Tech. Mem. NMFS-SEFC-251

Zimmerman, R. J., Minello, T. J., Zamora, G. (1984). Selection of vegetated habitat by brown shrimp, Penaeus aztecus, in a Galveston Bay salt marsh. Fish. Bull. U.S. 82 : 325-336

Zimmerman, R. J., Minello, T. J., Zamora, G., Martinez, E. (1986). Measurements of estuarine shrimp densities applied to catch predictions. In: Landry, A. M., Klima, E. F. (eds.) Proceedings of the shrimp yield prediction workshop. Publ. No. TAMU-SG-86-110, Texas A\&M Sea Grant, p. $38-55$ 